\title{
REJECTING THE POST-POLITICAL RESPONSE TO CLIMATE CHANGE: INTRODUCING THE EUROPEAN EGALITARIAN ENVIRONMENTALIST
}

\author{
Oscar Krüger, Mladen Domazet and Danijela Dolenec
}

\author{
Institute for Political Ecology \\ Preobraženska 2, 10000 Zagreb \\ e-mail: oscar.fellow@ipe.hr
}

\begin{abstract}
The phenomenon of climate change calls for a response and those who claim to be committed to creating such a response are known as environmentalists. In social research, much effort is spent in search for these environmentalists, and in trying to understand why they are found in certain geographical and social locations rather than others. One of the dominant views in environmental sociology holds environmentalism to be a position of the affluent.

This paper delivers a threefold provocation - conceptual, empirical and political - with the aim of shifting future research in another direction. Conceptually, it insists on the need to distinguish between post-political and political environmentalism, which is exemplified by the social movement called degrowth. Empirically, it is shown that the research which paints environmentalism as a position of the affluent relies on a post-political construal of what it means to be an environmentalist. It then shows how defining environmental value orientations more in lines with those of degrowth gives a very different map of environmentalism in Europe. Politically, this challenges established conceptions of what is realistic policy both for this continent and beyond. We conclude with a brief suggestion for the kind of politics that might be both politically feasible and capable of articulating an appropriate response to the challenge of climate change.
\end{abstract}

Keywords: climate change, environmentalism, semi-periphery, justice, degrowth

\section{INTRODUCTION}

That global climate is undergoing transformations as a consequence of human activity is all but universally accepted. ${ }^{1}$ The same is true for the notion that humans are reliant on the stability of their climate, and that the ensuing transformation poses a serious threat to them. Those who worry about this fact, and who are willing to take action, belong to the group of people called environmentalists. But where can we expect to encounter such environmentalists? Which conditions are conducive for cultivating the value orientations which define them? The answers we give to these questions are the foundational

1 See Dunlap and McCright (2011) for a discussion on those who still seek to digress. 
elements of any policy which seeks to respond to the challenge of climate change. One strong paradigm within the social sciences provides answers based on the assumption that such environmentalism is grounded in post-materialist value orientations, which are primarily found among the affluent (Inglehart and Baker, 2000; Gelissen, 2007; Franzen and Meyer, 2010; Nawrotzki, 2012). In this paper we challenge this position, both with respect to where it holds that environmentalists are to be found and, more fundamentally, what their defining characteristics are to begin with.

This challenge proceeds on two levels: In section 2 below, we scrutinize the dominant understandings of what environmentalism is really about in order to develop a more differentiated notion of it. We contrast the dominant "post-political" conception of environmentalism with "degrowth"-oriented environmentalism, associating the former with green consumption and the latter with concerns over distributive justice. This discussion takes place on the level on which the traits are defined, which empirical research then maps in its search for environmentalists. We argue that the position we seek to challenge stems from a definition centred on a willingness to pay for the sake of the environment, which is the hidden basis for the results of the so-called affluence hypothesis. Our discussion leads us to consider a very different kind of environmentalism.

In section 3, we employ this differentiation in order to revisit the very same empirical data that the position we rejected makes recourse to for advancing its claims. This data indeed testifies to the importance of affluence in Europe - but only to the extent that the dominant pre-conceptions of what characterises an "environmentalist" remain unchallenged. With particular focus on the European semi-periphery, we trace a pattern of concern with environmental issues that does not correlate with affluence. Instead, this pattern stands in an intimate relation with issues of inequality and commitments in favour of distributive justice, and hence we refer to it as egalitarian environmentalism. Once we demonstrate the contours of this egalitarian environmentalism, something significant will have been achieved: a challenge to the pre-conceptions of the relation that the European semi-periphery might take up with environmental politics; a challenge to how quantitative research has tended to go about searching for environmentalists; as well as a challenge to the conceptions which hold environmentalism to be a position of the affluent. This has political implications, including a strong case against positions that hold that the key for cultivating responsiveness to perils such as climate change is found in the generation of monetary wealth which would dispose people to pay more for 'greener products'. If our challenge is valid, then another kind of politics is needed. In section 4, we present a brief proposal as to what the politics might look like which would resonate with the kind of environmentalist value orientations we discuss in the preceding sections. Through such politics, a path may open ahead which does not rely on the growth of that social metabolism which drives climate change.

\section{VARIETIES OF ENVIRONMENTALISM}

Our purpose in this section is twofold: First, to scrutinize the paradoxes immanent to dominant environmentalisms. Doing so prompts the question whether an environmen- 
talism exists which is unbound by such paradox. We then suggest that this is the case for the positions which characterise the social movement known as degrowth. This discussion will outline the distinction between these environmentalisms, and show us why it is important to keep them apart. On the basis of this distinction, we then argue that much existing research on the distribution of environmentalists is shaped by a commitment to the kind of environmentalism we deem inadequate. By searching for commitments connected to the alternative form of environmentalism, a very different map of Europe might appear - which has implications also far beyond this continent. We follow up on this in the subsequent section.

The United Nations document Climate Action Now: Summary for Policymakers 2015 (United Nations Climate Change Secretariat, 2015) is a good example of what a conventional environmentalist policy response to climate change looks like. It proposes a shift towards renewable energy, energy efficiency, low-carbon transport and carbon capture, but does not touch upon the fundamentals of contemporary capitalist civilisation. This UN proposal is typical of the dominant framing of climate change, which has been argued to move rapidly from problem to diagnosis to cure, obviating any space of deliberation on what a truly appropriate response may look like (Szerszynski, 2010). In relying on expertise coupled with an avoidance of distributional and other conflicts, it epitomises a post-political framing wherein humanity is construed as a unified whole standing on the brink of imminent demise occasioned by an external force (Swyngedouw, 2010:217-221). This serves to blot out antagonisms, and inscribes our responses to climate change into a system of universalised administration that makes it (and us) subject to a purely managerial logic (Swyngedouw, 2010:225).

Would such efforts be enough? Many would disagree. For instance, the New Economics Foundation (Simms et al., 2010:66) models a scenario that incorporates all currently proposed policy proposals on energy use and carbon emissions, and the findings suggest that it would be near impossible to reach the emission goals posited by institutions such as the UN while maintaining present economic growth. Still, despite how the evidence of the trade-off between sustainability and economic growth is growing, in high level policy proposals like the UN Summary for Policymakers the reliance on economic growth remains unchallenged.

The claim that climate change is necessarily a so thoroughly post-political topic is challenged by John Urry (2011:91) who argues that such claims simply ignore the plethora of actual politicised responses to this issue. One such response, in the context of a response to the global environmental situation as such, is found within the social movement known as degrowth. Challenging the belief in the necessity, possibility and desirability of economic growth, this originally southern European movement is rapidly spreading across the continent and beyond (Demaria, et al. 2013; Muraca, 2013).

Degrowth today marks both a social movement and a conceptual framework within which to repoliticise the discussion of desirable development (Kallis et al., 2015). Conventional discussions of "development", it is argued, are oversaturated with economism, meaning a focus on the calculated economic outcome of every strategy or normative 
societal orientation (Martinez-Alier, 2015). Such economism overshadows the vulnerability of nature, aims for permanence, mutual aid and care, as well as creativity and the revolutionary potential of grassroots communities. As a result, the current dominant development model (criticized by this movement) holds improvements to well-being to be predicated on the growth of material consumption even for societies with a very high level of human development as measured by UNDP. In response, the degrowth social movement and theory attempt to reinterpret the fundamentally unsustainable condition of contemporary global society (Schaffartzik et al., 2014).

As a movement and a theory, degrowth deliberately plays on the shock value of challenging the secular dogma of economic growth. It serves as a missile concept in order to open up a conversation about what can and should be provided for humans and ecosystems alike. It ties in with the environmental justice movement in emphasising the interconnection of society, nature and the economy, and emphasises issues beyond a mere reduction of material flows. What remains must be distributed more equally, with greater popular control over production processes, bringing urban and rural spaces to a more equal footing (Anguelovski, 2015). Having said that, degrowth does not as yet provide an alternative paradigm with model problems and solutions for the scientific community, nor does it provide straightforward universal research instruments in the social sciences. Therefore, below we piece together loose strands from a piecemeal mapping of country potentials based on selected data sources.

The ecological stream of degrowth thinking stresses the current competition and future strategic trade-off between ecosystems and the industrial production and consumption systems. The democratic stream of degrowth champions debate and popular engagement over definitions of development and progress, and over struggles for justice, redistribution and technological intervention into social metabolisms. Motivated by these priorities of the degrowth movement, the environmentalism we are interested in exploring might be called "environmentally motivated democratic degrowth" (Domazet and Ančić, 2017), or a "growth-critical environmentalism". Such environmentalism, concerned fundamentally with social justice, rejects the post-political response to climate change that frames it as a problem that can be solved by relying on (techno-scientific) expertise (Swyngedouw, 2010).

These are the two kinds of environmentalism our discussion in this paper focuses on. If we turn to existing social research on the distribution of environmentalist value orientations, it will now be clear that much of this research implicitly understands environmentalism in the post-political terms set out above. For example, what is centrally important for Franzen and Meyer $(2010)^{2}$ in their search for environmentalists are questions about a person's willingness to pay higher prices and taxes in order to protect the environment; to accept cuts in his / her standard of living, and to act in favour of the environment also when doing so costs more money and time. This research implies that

2 This research is the most solid engagement from this angle with the same dataset that we discuss in section 3 below. 
concerned citizens are to be found where money is, and that environmentalism arrives in the wake of affluence (Diekmann and Franzen, 1999; Kemmelmeier et al., 2002; Meyer and Liebe, 2010; Franzen and Vogl, 2013). If "willingness to pay" is what defines an environmentalist, then it is perhaps not surprising that they are found among those already in possession of ample resources to pay with. In section 3, we begin an exploration of what the distribution of environmentalist value orientations may look like if we de-emphasise this kind of action. Here we seek to show that such results (those of e.g. Franzen and Meyer, 2010) do not show any viable path for generating popular support for the measures necessary for sustainability. Indeed, if the environmentalist as consumer profile is ultimately valid, we are stuck in an irresolvable paradox. Demonstrating this, we hope, is sufficient for motivating renewed scrutiny of such results.

One problem is illuminated when paying attention to the European semi-periphery, emphasizing its role as a semi-periphery. Unlike societies classified as "peripheral", this region is characterised by already high material standards of living. At the same time, here the concern for the environment appears even lower than what is the case for much of the periphery (Domazet and Ančić, 2017). Why is this so? The level of affluence relevant to how a person will answer the kind of questionnaires on which these conclusions are based appear to be contingent upon who they generally compare their position to (Domazet and Ančić, 2017:170). When such comparisons take place in terms of positional goods - goods whose very desirability is defined by their scarcity (Hirsch, 2005) - then, in a situation of inequity and insofar as affluence is the condition of sacrifice, no degree of economic growth will ever alone be sufficient to make the majority of people feel affluent enough to sacrifice for the environment. That intra-societal inequalities are also crucial for determining a person's feeling of well-being, and then probably affluence as well, is already well documented (Wilkinson and Pickett, 2010). In response to the last several decades of rising social inequalities in Europe, both East and West, contemporary social science has thematised the paralysing effect that inequality has on the social fabric of society (Milanovic, 2011; Sandel, 2012; Skidelsky and Skidelsky, 2012; Stiglitz, 2013). Driving this point forward, we suggest that this rising inequality is reflected in people's unwillingness to sacrifice personal consumption for the sake of the environment. Given that inequalities have grown faster in the European semi-periphery, this might help contextualise the apparently low levels of concern for the environment. Further, research shows how a $20 \%$ increase in the level of "development" is paid for by a $50 \%$ larger ecological footprint in a cross-national comparison of these European countries (Domazet and Marinović Jerolimov, 2014). Already at present there are significant differences in the contributions made to climate change by richer European nations and those which are poorer. For instance, European emissions trends seen on the comparative data for $\mathrm{CO}_{2}$ emissions from fossil fuels use and cement production (EC JRC, 2014) show that in poorer Eastern European countries that participate in the 2010 ISSP Environment module emissions have been almost halved from their peak level, whilst in richer Western European countries they have not even dropped by $20 \%$ (see Figure 1). Needless to say, they have been significantly lower in per capita volume 
to start with. With no precedence for major decoupling of environmental loads from growth (Bithas and Kalimeris, 2013; Kalimeris et al., 2014), it would appear that making people care for the environment comes at the price of further destroying it.

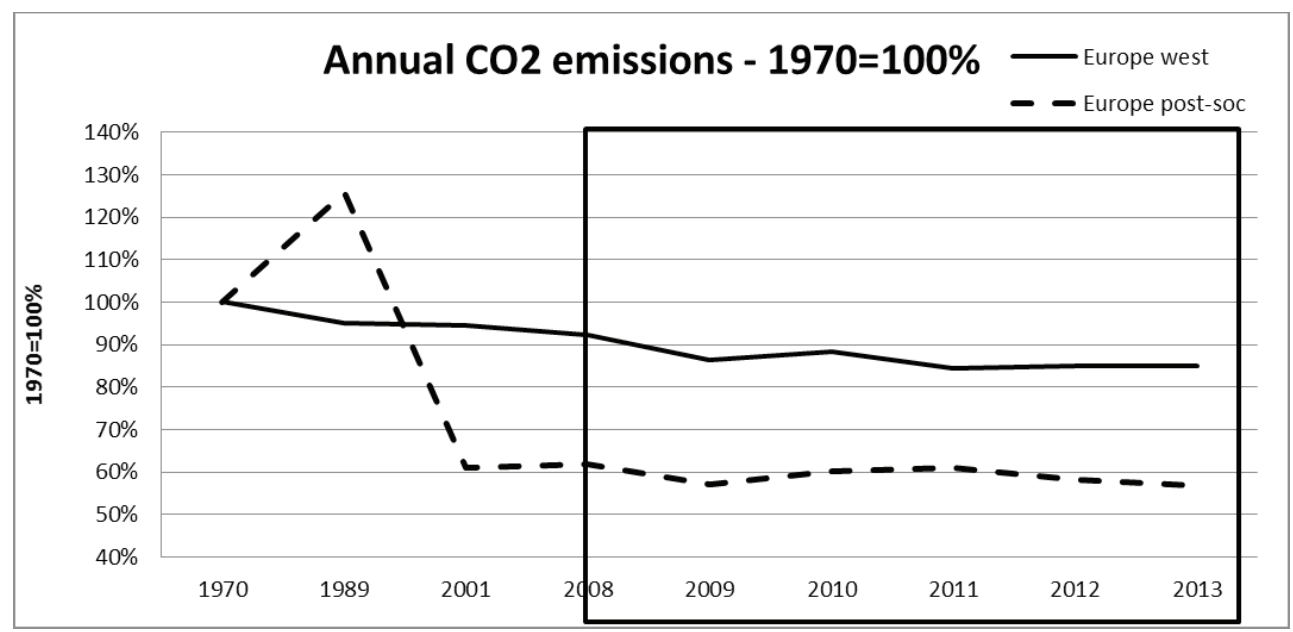

Source: European Commission, Joint Research Centre (JRC) / Netherlands Environmental Assessment Agency (PBL) (2014).

Figure 1. Change in annual $\mathrm{CO}_{2}$ emissions from 1970 for Western and post-socialist countries participating in the ISSP 2010 Environment module; with special emphasis on the 5 years from the last global economic crisis.

A third problem, if the affluence hypothesis possesses exclusive validity, appears if we attend to those affluent ones who do claim to be moved by moral concerns in their consumer choices: the well observed gap between such commitments and the propensity to actually follow up on them (Auger and Devinney, 2007). As Carrington, Zwick and Neville point out, there is a common tendency to treat this gap as a matter of individual shortcomings (2016:23). But doing so, the authors argue, fails to take into account the difference between the context where the questionnaire is answered, and the context where the purchase of a commodity is made. Whereas the questionnaire itself calls for conscious moral deliberation, such considerations are structurally excluded from the domain where consumer choices are made. Not only are moral deliberations not expected in this context, but market-actors are expected not to act on such concerns. Thus, the authors argue, the existence of the gap merely demonstrates that capitalism works as it is supposed to (Carrington et al., 2016:29). If things work as they are supposed to within a system predicated on a surplus of desire over productive output at any given time, then economic growth (which would need to be challenged in order to formulate an adequate response to climate change) remains the foundation of economic activity. Instead of being a legitimate concern, worry over "the gap" is itself part of an ideology that re-inscribes our worries into politics-as-usual. By presenting the consumer as a so- 
vereign in possession of the power to change the world through their consumer choices, growth-centred capitalism is made to appear salvageable if only these sovereigns can bring themselves to close the gap between their sentiments and their actions (Carrington et al., 2016:31). Thus, the option of translating those sentiments into more radical action is foreclosed (Carrington et al., 2016:24).

In light of the above, research which profiles environmentalists in these conventional terms is unlikely to find either conditions that can be cultivated so to generate the subjectivities it finds, nor will it find those poised towards adequate response to climate change in the first place. How significant is the apparent lack of such environmentalists in the European semi-periphery then really? Perhaps, instead, we ought to renew the terms that structure the scope of our search. One starting point for doing so is the classic work by Martinez-Alier (2002), which proposes a threefold division of environmentalism-s: the cult of wilderness, the gospel of eco-efficiency, and the environmentalism of the poor. The first environmentalism is concerned with untouched nature, the second includes environmental impacts of productive processes, and the third is characterised by a concern with inter-human justice (Martinez-Alier, 2002:1-11).

Like Martinez-Alier, it is the latter that we wish to expound upon, when we now attempt to orientate ourselves towards the value orientations we would associate with degrowth-environmentalism. Beyond those who are explicitly dedicated to such an environmentalism, the commitments we associate with it are such we would expect among marginalised groups rather than the affluent. Perhaps contributing to their absence from the sort of research we criticise in this paper, these concerns are often voiced by people who are facing concrete impacts at extractive frontiers, but who do not necessarily think of themselves as "environmentalists" (Martinez-Alier, 2002:11). There is no shortage of conflicts occasioned by such processes in the European semi-periphery (Temper, 2015; EJatlas, 2016). If we were to call these people "environmentalists" regardless, and decide to investigate their distribution within Europe, what characteristics should we look for? Instead of searching for those that profess a willingness to pay for a clean environment, we would search for concerns over distributive economic justice, for worries over the effects of relentless economic growth, and for those experiencing the present environmental situation as posing risks. We have now differentiated two kinds of environmentalism, and shown how much existing research maps but one of these. Arguing that this environmentalism is insufficient for meeting the demands posed by climate change and related issues, we hope that the need for attending to environmentalism of the second kind has been made clear. In the following section, we synthesize emerging research on this issue, which indicates where such attention may lead.

\section{ENVIRONMENTALISM IN EUROPE}

Our purpose in this section is to discuss how the existing empirical data which supports the affluence hypothesis can be re-interpreted in light of the differentiation of environmentalisms discussed above. Our polemic joins the body of studies questioning the do- 
minance of the affluence hypothesis, not through a novel statistical analysis, but rather through deconstruction of the central role afforded to green consumerism in constructs of comparative statistics. We do this through a review of recent studies on the distribution of social attitudes towards environmentalism in Europe, based largely on ISSP ${ }^{3}$ data (ISSP, 2012) and various aggregate country indicators. In doing so, we focus on that part of the semi-periphery that is usually referred to as post-socialist Europe. Relying on standard comparative survey data means we are confined to tracing correlations on the level of national averages, which is far from perfect, but this way we get to challenge the dominant interpretations at the very foundations that support them. Insofar as the national level remains an important avenue for negotiating political responses to climate change, this is also an appropriate level for thinking through the potential receptiveness of various policies and strategies.



Source: Reprinted from Domazet and Marinović Jerolimov (2014).

The 18 countries participating in the ISSP 2010 Environment module (ISSP, 2012) are marked in a lighter colour.

Abbreviations: GNI=Gross National Income (almost identical to GDP in the case of Europe); $H D I=$ Human Development Index (UNDP).

Figure 2. GNI per capita - HDI (2012) values spread for European countries, excluding Lichtenstein.

3 The International Social Survey Programme (ISSP) is an academic-led and globally coordinated programme gathering data for comparative research on different topics. The data primarily drawn on here comes from the Environment module fielded in 2010 and 2011. This module included 60 questions on environmental attitudes and behaviours, and a comprehensive set of background variables; it was fielded in 36 countries globally and the national samples are representative of the adult population of each country. The first version of the dataset that most of the analyses reviewed here relied on was published by the German data archive GESIS in 2012 (ISSP, 2012). 
Even though all nations in Europe are ranked as "high human development" by UNDP's HDI measure, for some of them further economic growth may still bring gains to their human development score, as suggested by Figure 2. As Figure 2 illustrates, all national HDI scores fall above the global cut-off point where the increasing GNI (or GDP) brings a comparatively lower HDI contribution (this cut-off point is usually around 10000 USD pc and 0.7 HDI value), but the scatter in the graph indicates a possible second cut-off point within Europe. This point stands just below 30000 USD pc, above which the rise in HDI is almost negligent. Most European countries, many of them represented in the ISSP 2010, are still below this value of GNI pc, and could possibly gain further increases in HDI with rising per capita GNI.

As argued in the preceding section, many comparative cross-national analyses applying multilevel modelling to the distribution of environmentalism predicated on environmental concern are based on the assumption that such development-through-growth holds the key for cultivating the value orientations required for a democratic answer to climate change. This affluence hypothesis rests on the premise that environmental health and stability is like a commodity for which the demand rises with the affluence of individuals, and consequently of whole societies. It also presupposes that the most meaningful and widespread action on behalf of the environment is mediated through a mechanism of demand and willingness to pay for desirable goods. The "environment" becomes a good that richer societies will more readily afford and seek out (Diekmann and Franzen, 1999; Franzen, 2003; Meyer and Liebe, 2010; Franzen and Meyer, 2010). Whilst competing interpretations of differences in values, concerns, self-reported behaviour and cultural practices related to environment exist both in sociology (Fairbrother, 2012; Knight and Messer, 2012) and in the humanities, the affluence hypothesis has a particularly strong sway in survey-based comparative analyses (Dunlap, 2017). In such studies (Kemmelmeier, et al., 2002; Franzen, 2003; Gelissen, 2007; Marquart-Pyatt, 2008; Franzen and Meyer, 2010; Nawrotzki, 2012; Franzen and Vogl, 2012; Franzen and Vogl, 2013) affluence is a strong predictor of national differences in environmental concern among European nations, which are culturally and developmentally similar when viewed from a global perspective (Marquart-Pyatt, 2012a; Ančić and Domazet, 2015; Schaffrin and Schmidt-Catran, 2017).

Also, the less quantitatively-driven analyses often argue that the attained level of material comfort provides different prerequisites in different societies for the sacrifices required for the transformation of material and social infrastructure (Helm and Simonis, 2001; Boehmer-Christiansen, 2003; Timmons Roberts and Parks, 2010; Princen, 2010; Wapner, 2010). When sacrifice is theoretically based on a willingness to pay, a specific statistical weighting of cultural predispositions leads to the confirmation of the affluence hypothesis across different cross-national and longitudinal datasets such as the ISSP, WVS ${ }^{4}$ and EVS 5 (cf. Franzen and Vogl, 2012). Fundamentally, the logic of this conclusion can be glossed

4 WVS: World Values Survey.

5 EVS: European Values Survey. 
as: "more money, more development, more environmental concern, greater readiness to act on global climate change". Though by no means exclusive or solely triumphant, the affluence hypothesis is of particular significance both because of its ease of translation into the economist discourse that has a great influence on policy today, and because of the economism-minded ${ }^{6}$ way it is defined and measured (Dunlap, 2017).

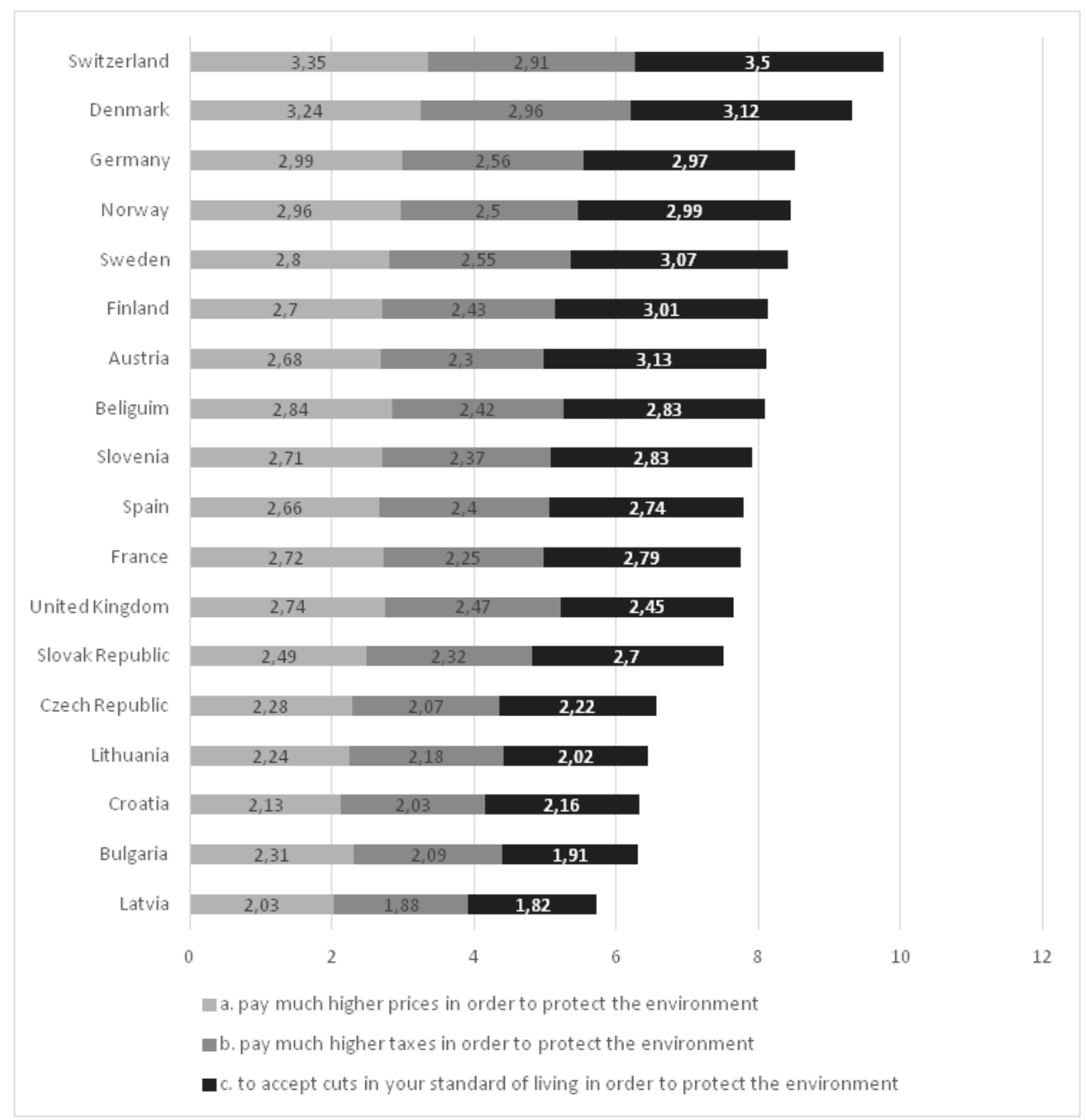

Source: Reprinted from Domazet et al. (2014).

Figure 3. Composite indicator of "Material sacrifice attitudes", higher value signifies more prevalent "willingness to pay" within a national population.

6 Economism is a discursive reduction of broad social facts to economic dimensions.

7 In terms of functional analysis of the world-systems theory, not a political value judgement. 
The "get richer to get greener" maxim has direct implications for the materially poorer and supposedly less environmentalist populations of the European semi-periphery. Whilst their level of development allows them to be readily compared against more affluent core ${ }^{7}$ European nations, the ability of their populations to pay for "environment" as a commodity is objectively lower, supposedly making them politically unable to commit to the required material sacrifices. Now, does existing data actually support any of these assumptions?

On an immediate level, it appears that the answer is "yes". Our research (Domazet et al., 2014; Dolenec et al., 2014; Domazet and Ančić, 2017) confirms that "willingness to pay" for environmental protection is correlated with national income, even when we adjust for income inequality at the national level. GDP per capita and associated GNI along with inequality-adjusted income index are the strongest predictors of the prevalence of such attitudes (Domazet et al., 2014:163-165). As a result, countries of the European semi-periphery are mostly at the lower part of Figure 3 . On face value we might indeed conclude that the populations of the European semi-periphery are simply too preoccupied with material development to pay attention and exemplify sufficient awareness to environmental issues.

Nevertheless, it is precisely when focusing on such things as "paying attention and expressing awareness" of seriousness of environmental problems, that the already existing data suggests something else. As Figure 4 indicates, semi-peripheral (Eastern and Southern European) populations that occupy the lower part of the scale in Figure 3 in many cases occupy the inverse position when it comes to concern over climate change. In any case, in the ISSP dataset reported on before, as well as in the Eurobarometer dataset in Figure 3 , attaching serious concern to climate change is more prevalent among Southern and Eastern European countries.

In our version of the argument, environmental concern is not simply a value orientation, but a perception of direct, real environmental threats (Brechin, 1999; Dunlap and York, 2008). In the literature that focuses on the experience of environmental degradation in developing countries, this second variety of concern has been conceptualised as the "environmentalism of the poor" introduced above (Martinez-Alier, 2002). Dolenec et al. (2014) explore this variety of environmentalism, looking for evidence of sustainability orientations in less affluent European societies. They start from two assumptions: that inequality of income and of material life circumstances pose obstacles to sustainability orientations in European societies, and that, while wealthier societies exhibit stronger environmental concern overall, perceptions of direct environmental risk is stronger in the European semi-periphery. These results, as well as those of Brajdić Vuković (2014), clearly show that respondents from less affluent European countries are more aware of environmental risks than respondents from affluent ones. Even more importantly, these findings support Haanpääs (2006; on ISSP dataset) and Knight and Messer's (2012; on WVS dataset) arguments according to which poorer populations may have a stronger perception of direct, real environmental threats despite not expressing great individual activation and commitment to personal material sacrifice. 


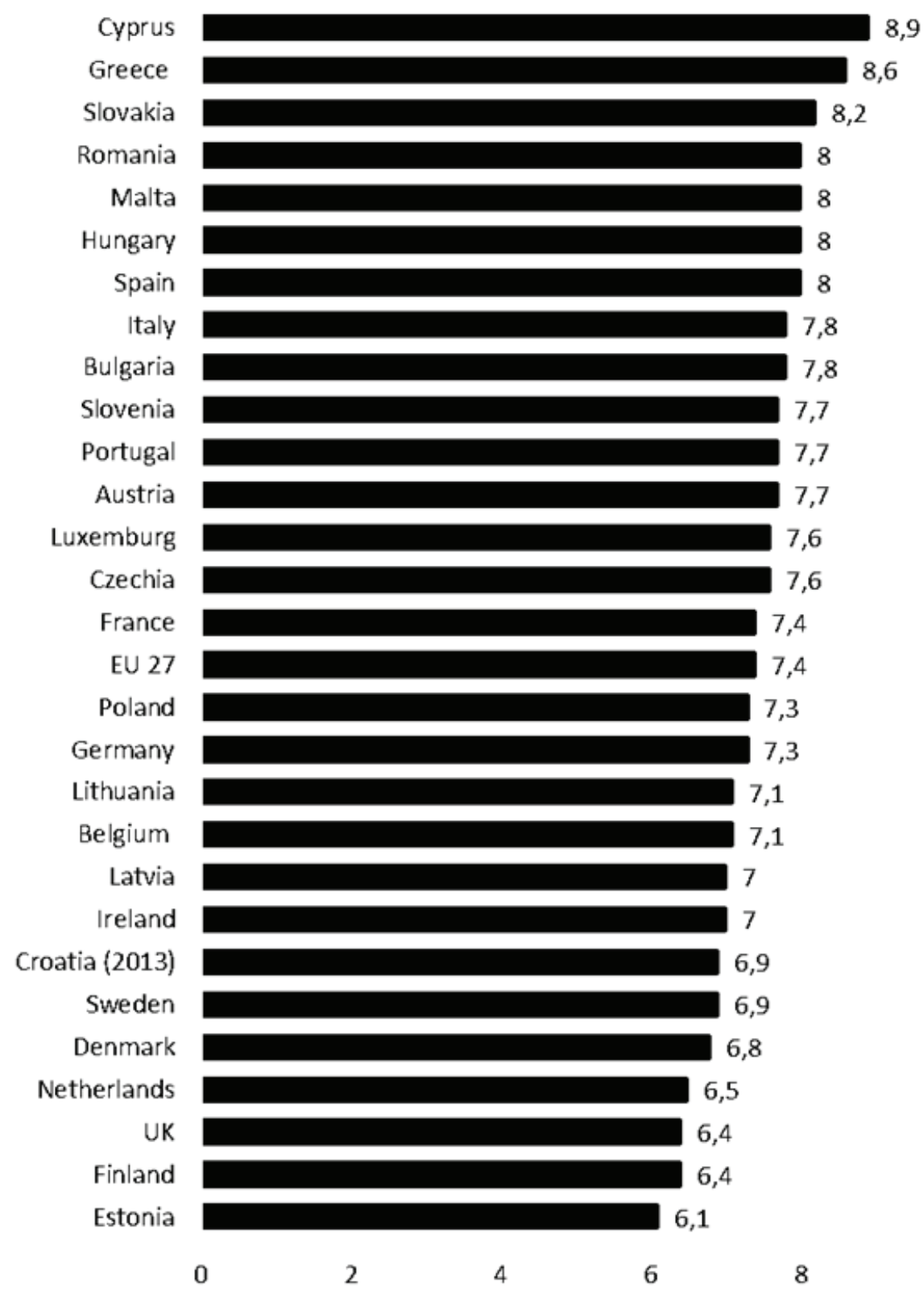

Source: Amended dataset from Eurobarometer Climate Change (2011). Translated and transposed from Ančić et al. (2016).

Figure 4. Indicator "Climate change as a serious problem" (2011; 2013 in case of Croatia) - mean values of the response by EU member country and Croatia. 
Thus, despite being poorer and "less developed" on average, the European semi-periphery does not stand out as negligent, non-environmentalist or as lacking concern over climate change. Also, on a composite indicator which, in addition to climate change, measures concerns over pollution, GMOs and nuclear energy, this trend is repeated for such comparisons between richer, poorer, core and semi-peripheral European nations (Haanpää, 2006; Dolenec et al., 2014; Brajdić Vuković, 2014). Even in Eurobarometer surveys conducted on all contemporary European member states, concern over climate change as a global problem does not differ significantly across European regions even though it fluctuates overall and within individual countries (EC, 2008; EC, 2014). Beyond concern, beliefs and attitudes, environmental risks - that is, an expectation that a particular phenomenon in the physical environment will have negative consequences to oneself and society - are experimentally associated with the spur to pro-environmental behaviour (Brechin, 1999; Marquart-Pyatt, 2012b). Sometimes people will act out in order to minimise risks, and not just to stay true to their beliefs and concerns. According to O'Connor et al, (1999:469), risk perceptions are "not a surrogate for general environmental beliefs, but have their own power to account for behavioural intentions". At the same time, they are also socially constructed, in as much as their "reality" is mediated by social knowledge and dominant socio-political context of a given society (Spangenberg, 2005; Beck, 2010).

Since we review national averages, this does not let us determine conclusively whether or not the value orientations we choose to emphasise might primarily be found among the affluent within the national units (Ančić and Domazet, 2015). However, taken together, the results above indicate that the traits we expected to characterise respondents who are receptive to growth-critical environmentalism do not correlate with differences in national affluence. These kinds of subjectivities, which we may tentatively call "passive degrowthers" - concerned with environmental limits but not presently engaged in environmental activism - represent approximately $20-40 \%$ of national populations across European countries, regardless of national average affluence, development attainment, GHG emissions or ecological footprint (Ančić and Domazet, 2015; Balžekiene and Telešiene, 2017; Schaffrin and Schmidt-Catran, 2017). Hence we argue that it is a fallacy to expect that only affluent societies hold value orientations important for the switch to sustainability. The European continent is not divided into an affluent core and a lagging semi-periphery too busy catching up to be concerned with climate change. Less affluent European societies, where large segments of the society are exposed to risk of poverty and various forms of material insecurity, exhibit important features of environmentalism not based on consumer choice (Domazet and Ančić, 2017).

Populations in less affluent European societies exhibit a higher awareness of the risks posed by environmental degradation. What about the other concerns we associate with egalitarian environmentalism discussed in section 2? That is, concerns with power relations, ecological distributional conflict, and equity. As a phenomenon, in-equity has a measurable importance for environmentalism: regardless of which measure of inequality we used, it proved corrosive for environmental concern, readiness for material 
sacrifice and, no less important, the preparedness of people to trust each other (Dolenec et al., 2014). Such findings corroborate arguments according to which the relationship between rise in income and environmental protection is anything but automatic (Grossman and Krueger, 1995; Knight and Messer, 2012). When economic development is not accompanied by a more equitable distribution of power and income within society, environmental sustainability is directly jeopardised. Further, more than just presenting it as something which is found in contexts of inequality, Martinez-Alier (2002) associates "environmentalism of the poor" with direct claims for distributive justice. The populations of these countries exhibit stronger redistributive preferences, which arguably represent a crucial aspect of a determined societal effort for a shared wellbeing with lower environmental and climate impact (Dietz et al., 2005; Hansla et al., 2013; Dolenec et al., 2014).

To conclude, we must reconsider the received wisdom about where environmentalists are to be found. The studies we reviewed here suggest that awareness of the environmental limits of growth is not guided by national wealth in the way that self-reported readiness to act on it is. Is it then simply in regards to a self-reported willingness to take certain actions - in particular, a "willingness to pay" - that the European semi-periphery lags behind? We suggest that what matters for sustainability, as understood from a degrowth perspective, may well be a more equitable distribution of power within society, which may or may not occur with economic development and GDP growth. Following Torras and Boyce (1998:150), we agree that "distribution of power is not a peripheral concern" - on the contrary, a more equitable income distribution combined with stronger political rights and individual emancipation are key factors in garnering public support for the reorientation towards environmentally sensible trajectories. Perhaps the pan-European environmentalist may not be a "green consumer", but an egalitarian willing to challenge a social system based on infinite economic growth. In the fourth and final section, we propose one implication of this.

\section{ENVIRONMENTALISM AND JUSTICE}

In section 1, we argued that the kind of commitments which are often designated by the word "environmentalism" are insufficient for the challenges of our present situation. In section 2, we demonstrated how the commitments associated with a more adequate form of environmentalism are not correlated with the same social conditions as those which define an environmentalist for much conventional research. Instead of affluence, "justice" and "equity" began to appear as crucial elements for egalitarian environmentalism. In this section, we would like to offer a tentative suggestion as to what these two elements might imply politically when taken together. The basic conundrum is this: Economic growth ensures the continuous generation of many such things as people presently find valuable. If a politics of equity is to call for something other than equal participation in the process of committing ecocide (Tammilehto, 2014), then it needs to articulate a challenge to this very regime of valuation. What mode of deliberating upon justice lets this be done? 
A focus on inequality introduces the question of power into the analysis (Dolenec et al., 2014), and the need to clearly state who wins, who loses out, and what defines either. This is a question of justice, and much has been written on that topic in relation to climate change (Barker et al., 2008; Preston et al., 2014). As for economic growth, which is our more immediate concern here, one very compelling suggestion as to what paradigm of distributive justice is appropriate for evaluating the phenomenon of growth as such is articulated by philosopher Barbara Muraca. What Muraca (2012) challenges is the established paradigms of "welfarism" (e.g. Layard; rejected for its utilitarian assumptions and reliance on self-reported states) and "resourcism" (e.g. Rawls; rejected for its concern with good "things" rather than the influence of these things on human lives, which may require very different resources in order to function). This leaves the "capabilities-approach", which Muraca adopts from Sen and Nussbaum (Muraca, 2012). As we read it, her argument for the superiority of this paradigm over the others hinges on the same characteristic: that "justice" is determined in relation to a certain kind of good that a person has reason to value (Muraca, 2012:538). This means that, unlike what is the case for welfarism, there is a demand for a justification for preferences; and unlike resourcism, the allocation of "resources" is evaluated only in light of what is so justified. Justice, in this sense, takes its measure from what can be recognised as legitimate in aspirations. This, according to Muraca, implies that "a 'just' degrowth society, in which claims for the good life are constitutive for justice, is only possible if patterns of recognition and established values are renegotiated" (Muraca, 2012:543).

To establish what is just in any given situation would thus imply recourse to the values which determine what it means to be so, which is in turn negotiated in view of substantive visions of the meaning of "the good life". The content of such visions, of course, is also subject to negotiation. The significant point is that distributive justice would then not be limited to rectifying asymmetries in a way that merely assures more equal access to consumer goods. In the opening of such a space of negotiation, furthermore, the concern for "justice" that is immanent to environmental ideologies (of the kind that section 1 above outlines and section 2 traces self-reported concerns for) may be translated into a voluntary social transformation to meet the challenge of climate change.

Therefore, in such terms, negotiations over justice would measure up to the demands derived from the first section of this paper. As for the popular engagement such negotiations may resonate with, we would like to offer an even briefer connection with John Meyer's (2010) discussion on environmentally motivated sacrifice among blue collar workers. This is a group which, like Eastern Europeans, is traditionally seen as reluctant to such sacrifice. What Meyer notes is that such workers are, in fact, traditionally animated by an ethos of sacrifice in a way which, however, demands that the sacrifice is recognised and reciprocated (Meyer, 2010:24). In the space of negotiation, which questions of justice can create if approached in the form advanced in this section, the task of answering the challenge of climate change can let us designate differentiated rights and duties by way of mutual recognition and reciprocity. This is quite distinct from moralising exhortations in a society characterised by inequality, where those themselves experiencing having less of that which 
is socially recognised as desirable are implored to sacrifice their pursuit of that which they lack. If popular commitment to such "sacrifice" is necessary for a democratic response to climate change to take place, then our search for a way out of our present predicament will be egalitarian and democratic, or it will not work - these are not mere normative ends, but the means to achieve a switch to sustainability.

In a nutshell, the concentration of power and growing income inequalities pose fundamental obstacles to achieving sustainable human development. When material conditions of life and resulting life chances become as vastly disparate as they are today, people lack a basic sense of shared humanity without which we cannot engage in a democratic debate on the features of a just society (Wright, 2011). Therefore, reducing inequality and ensuring basic human security are necessary ingredients in the reorientation towards sustainability. In addition to that, we must not lose focus of the fact that, while sustainable or unsustainable practices are a matter of choice, "for too many people on Earth the problem is not unsustainable choices, but a lack of choice in the first place" (Dolenec et al., 2014). In this context, abandoning those activities that contribute to the present climate change may no longer be experienced as self-abnegating, as much as affirmative of a joyful participation in an extended human community.

\section{CONCLUDING REMARKS}

This paper draws together theoretical, empirical and political concerns, couched in tentative language such as "perhaps" and "suggest". Both are symptomatic of what we hope to achieve, which is to raise an opening for enquiry. The opening we hope to create is crucial to our ability to find a new way through the predicament of climate change. Present responses to this change are inadequate, and our discussion indicates ways in which resistance to appropriate measures may be products of something at the very foundations of our dominant socio-political context, rather than in quirks that can be repaired. Thus, our discussion is intended to advance a critique of environmentalism as perceived within the dominant capitalist paradigm. In a different kind of social context, the widespread concern with climate change might find ways to be translated into adequate action. Our way of advancing such a position is, in this paper, focused on attending to some of those who are traditionally perceived as reluctant to answer the demands posed by environmental degradation. In section 2 we argued that the actions these populations might really be reluctant towards are, in fact, themselves inadequate. There are other ways of conceiving meaningful environmental action, which would proceed along other lines. In section 3 we interrogated whether or not the data that confirms the absence of conventionally defined "environmentalists" in the European semi-periphery might not also show the contours of that which we associate with the alternative, preferable, form of egalitarian environmentalism. Under our new scrutiny, the distribution of European environmentalism was shown to look very different than received wisdom expects it to: "Environmentalist" value orientations were shown to be as prevalent (or more) in the European semi-periphery as they are in its core. 
Our demonstration has implications for widespread notions of the condition for environmentalism, which is often taken to be that of affluence. While affluence may hold the key to various forms of green consumerism, it does not do so for environmental threats perception, risks, and values related to global development strategies (cf. Haller and Hadler, 2008). Such concern may, in fact, be more conducive for what we propose in section 1 to be a more appropriate form of environmentalism. This form of egalitarian environmentalism would not treat "the environment" as an isolated issue, but integrate it within a programme of social transformation. In section 4 we proposed the outlines of a kind of social deliberation that may resonate with the sensibilities we trace in the preceding sections. Within such a venue, we believe, there are ways of formulating answers to climate change that are both adequate and generated through a process built on broad consent. Thus, the opening we seek to pry in the debate on the features of environmentalism may, quite possibly, let us uncover a way for Europe to respond to climate change - and to do so in a way that is not abnegating but, ultimately, liberating.

\section{REFERENCES}

Ančić, B., and Domazet, M. (2015). Potential for Degrowth: Attitudes and Behaviours across 18 European Countries. Teorija in Praksa, 52(3): 456-475.

Ančić, B., Puđak, J., Domazet, M. (2016). Vidimo li klimatske promjene u Hrvatskoj? Istraživanje stavova o nekim od aspekata klimatskih promjena u hrvatskom društvu. Hrvatski meteorološki časopis, 51: 27-45.

Anguelovski, I. (2015). Environmental justice. In: D’Alisa, G., Demaria, F., Kallis, G. (eds.), Degrowth: A vocabulary for a new era (pp. 33-36). Abingdon: Routledge.

Auger, P. and Devinney, T. M. (2007). Do What Consumers Say Matter? The Misalignment of Preferences with Unconstrained Ethical Intentions. Journal of Business Ethics 76(4): 361-383.

Balžekiene, A. and Telešiene, A. (2017). Vulnerable and insecure? Environmental and technological risk perception in Europe. In: Telešienè, A. and Gross, M. (eds.), Green European. Environmental Behaviour and Attitudes in Europe in a Historical and Cross-Cultural Comparative Perspective (pp. 31-55). Abingdon: Routledge.

Barker, T., Scrieciu, S., Taylor, D. (2008). Climate change, social justice and development. Development, 51(3): 317-324.

Beck, U. (2010). Climate for change, or how to create a green modernity? Theory, Culture \& Society, 27(2-3): 254-266.

Bithas, K., and Kalimeris, P. (2013). Re-estimating the decoupling effect: Is there an actual transition towards a less energy-intensive economy? Energy, 51: 78-84.

Boehmer-Christiansen, S. (2003). Science, Equity and the War against Carbon. Science, Technology \& Human Values, 28: 69-72.

Brajdić Vuković, M. (2014). The sustainability potential of the knowledge society: Empirical study. In: Domazet, M. and Marinović Jerolimov, D. (eds.), Sustainability 
Perspectives from the European Semi-periphery (pp. 195-222). Zagreb: Institut za društvena istraživanja u Zagrebu and Heinrich Böll Stiftung-Hrvatska.

Brechin, S. R. (1999). Objective problems, subjective values, and global environmentalism: Evaluating the postmaterialist argument and challenging a new explanation. Social Science Quarterly, 80(4): 793-809.

Carrington, M. J., Zwick, D., Neville, B. (2016). The ideology of the ethical consumption gap. Marketing Theory, 16(1): 21-38.

Demaria, F., Schneider, F., Sekulova, F., Martinez-Alier, J. (2013). What is degrowth? From an activist slogan to a social movement. Environmental Values, 22(2): 191-215.

Diekmann, A., and Franzen, A. (1999). The wealth of nations and environmental concern. Environment and behavior, 31(4): 540-549.

Dietz, T., Fitzgerald, A., Shwom, R. (2005). Environmental Values. Annual Review of Environment and Resources 30: 335-372.

Dolenec, D., Domazet, M., Ančić, B. (2014). Why power is not a peripheral concern: Exploring the relationship between inequality and sustainability. In: Domazet, M. and Marinović Jerolimov, D. (eds.), Sustainability Perspectives from the European Semi-periphery (pp. 173-194). Zagreb: Institut za društvena istraživanja u Zagrebu and Heinrich Böll Stiftung-Hrvatska

Domazet, M., Ančić, B., Brajdić Vuković, M. (2014). Prosperity and environmental sacrifice in Europe: Importance of income for sustainability-orientation. In: Domazet, M. and Marinović Jerolimov, D. (eds.), Sustainability Perspectives from the European Semi-periphery (pp. 145-172). Zagreb: Institut za društvena istraživanja u Zagrebu and Heinrich Bőll Stiftung-Hrvatska.

Domazet, M., and Marinović Jerolimov, D. (2014). Sustainability on the semi-periphery: an impossible topic in a non-existent place? In: Domazet, M. and Marinović Jerolimov, D. (eds.), Sustainability Perspectives from the European Semi-periphery (pp. 19-49). Zagreb: Institut za društvena istraživanja u Zagrebu and Heinrich Bőll Stiftung-Hrvatska.

Domazet, M. and Ančić, B. (2017). How far for the money? Affluence and democratic degrowth potential in Europe. In: Telešienè, A. and Gross, M. (eds.), Green European. Environmental Behaviour and Attitudes in Europe in a Historical and CrossCultural Comparative Perspective (pp. 157-181). Abingdon: Routledge.

Dunlap, R. E. (2017). Foreword: A brief history of sociological research on environmental concern. In: Telešiene, A. and Gross, M. (eds.), Green European. Environmental Behaviour and Attitudes in Europe in a Historical and Cross-Cultural Comparative Perspective (pp. 19-26). Abingdon: Routledge.

Dunlap, R. E. and York, R. (2008). The Globalization of Environmental Concern and the Limits of the Post-Materialist Explanation: Evidence from Four Cross-National Surveys. Sociological Quarterly, 49: 529-563.

Dunlap, R. E., and McCright, A. M. (2011). Organized climate change denial. In: Honig, A. P. B., and Dryzek, J. (eds.), Oxford Handbook of Political Theory (pp. 144160). Oxford: Oxford University Press. 
EJatlas. (2016). Environmental Justice Atlas. URL: http://ejatlas.org/ (July 14, 2016). European Commission (2008). Europeans' attitudes towards climate change. Special Eurobarometer 322.

European Commission (2014). Climate change. Special Eurobarometer 409.

European Commission, Joint Research Centre (EC JRC) / Netherlands Environmental Assessment Agency (PBL). (2014). Emission Database for Global Atmospheric Research (EDGAR), release CO2 time series 1970-2013. URL: http://edgar.jrc. ec.europa.eu. (June, 2015).

Fairbrother, M. (2012). Rich People, Poor People, and Environmental Concern: Evidence across Nations and Time. European Sociological Review, 29: 910-922.

Franzen, A. (2003). Environmental attitudes in international comparison: An analysis of the ISSP surveys 1993 and 2000. Social Science Quarterly, 84(2): 297-308.

Franzen, A., and Meyer, R. (2010). Environmental attitudes in cross-national perspective: A multilevel analysis of the ISSP 1993 and 2000. European Sociological Review, 26(2): 219-234.

Franzen, A. and Vogl, D. (2012). Acquiescence and the Willingness to Pay for Environmental Protection: A Comparison of the ISSP, WVS, and EVS. Social Science Quarterly, 93(3): 637-659.

Franzen, A. and Vogl, D. (2013). Two decades of measuring environmental attitudes: A comparative analysis of 33 countries. Global Environmental Change, 23(5): 1001-1008.

Gelissen, J. (2007). Explaining popular support for environmental protection - A multilevel analysis of 50 nations. Environment and Behavior, 39(3): 392-415.

Grossman, G. M., and Krueger, A. B. (1995). Economic Growth and the Environment. The Quarterly Journal of Economics, 110(2): 353-377.

Haanpää, L. (2006). Environmental Concern Worldwide: An Examination of TwoWay Thesis of Environmentalism and National Variation. In: Wilska, T. A. and Haanpää, L. (eds.), Lifestyles and Social Change. Essays in Economic Sociology (pp. 179-204). Tampere: Esa.

Haller, M. and Hadler, M. (2008). Dispositions to Act in favour of the Environment: Fatalism and Readiness to Make Sacrifices in Cross National Perspective. Sociological Forum 23(2): 281-311.

Hansla, A., Gaerling, T., Biel. A. (2013). Attitude toward environmental policy measures related to value orientation. Journal of Applied Social Psychology 43(3): 582-590.

Helm, C. and Simonis, U. E. (2001). Distributive Justice in International Environmental Policy: Axiomatic Foundation and Exemplary Formulation. Environmental Values, 10(1): 5-18.

Hirsch, F. (2005). Social limits to growth (e-book edition). London: Routledge.

Inglehart, R. and Baker, W. E. (2000). Modernization, cultural change, and the persistence of traditional values. American Sociological Review, 65(1): 19-51.

ISSP Research Group (2012). International social survey programme: Environment III - ISSP 2010. Cologne: Gesis Data Archive. ZA5500 Data file version 2.0.0, doi:10.4232/1.11418 
Kalimeris, P., Richardson, C., Bithas, K. (2014). A meta-analysis investigation of the direction of the energy-GDP causal relationship: implications for the growth-degrowth dialogue. Journal of Cleaner Production, 67: 1-13.

Kallis, G., Demaria, F., D’Alisa, G. (2015). Introduction: degrowth. In: D’Alisa, G., Demaria, F., Kallis, G. (eds.), Degrowth: A vocabulary for a new era (pp. 1-18). Abingdon: Routledge.

Kemmelmeier, M., Krol, G., Kim, Y. H. (2002). Values, economics, and proenvironmental attitudes in 22 societies. Cross-Cultural Research, 36(3): 256-285.

Knight, K. W. and Messer, B. L. (2012). Environmental Concern in Cross-National Perspective: The Effects of Affluence, Environmental Degradation, and World Society. Social Science Quarterly, 93(2): 521-537.

Kothari, A., Demaria, F., Acosta, A. (2014). Buen Vivir, Degrowth and Ecological Swaraj: Alternatives to sustainable development and the Green Economy. Development, 57(3-4): 362-375.

Marquart-Pyatt, S. T. (2008). Are there similar sources of environmental concern? Comparing industrialized countries. Social Science Quarterly, 89(5): 1312-1335.

Marquart-Pyatt, S. T. (2012a). Environmental Concerns in Cross-National Context: How Do Mass Publics in Central and Eastern Europe Compare with Other Regions of the World? Czech Sociological Review, 48(3): 441- 466.

Marquart-Pyatt, S. T. (2012b). Contextual Influences on Envrionmental Concerns Cross-Nationally: A multilevel Investigation. Social Science Research, 41(5): 1085-1099.

Martinez-Alier, J. (2002). The environmentalism of the poor: a study of ecological conflicts and valuation. Cheltenham: Edward Elgar Publishing Limited.

Martinez-Alier, J. (2015). Environmentalism, currents of. In: G. D’Alisa, G., Demaria, F., Kallis, G. (eds.), Degrowth: A vocabulary for a new era (pp. 37-40). Abingdon: Routledge.

Meyer, J. M. (2010). A democratic politics of sacrifice? In: Maniates, M. and Meyer, J. M. (eds.), The environmental politics of sacrifice (pp. 13-32). Cambridge, MA: Massachusetts Institute of Technology Press.

Meyer, R., and Liebe, U. (2010). Are the affluent prepared to pay for the planet? Explaining willingness to pay for public and quasi-private environmental goods in Switzerland. Population and Environment, 32(1): 42-65.

Milanovic, B. (2011). Worlds apart: Measuring international and global inequality. Princeton, NJ: Princeton University Press.

Mol, A. and Spaargaren, G. (2000). Ecological modernization theory in debate: a review. Environmental Politics, 9(1): 17-49.

Muraca, B. (2012). Towards a fair degrowth-society: Justice and the right to a 'good life' beyond growth. Futures, 44(6): 535-545.

Muraca, B. (2013). Décroissance: A project for a radical transformation of society. Environmental Values, 22(2): 147-169.

Nawrotzki, R. J. (2012). The Politics of Environmental Concern: A Cross-National Analysis. Organization \& Environment, 25(3): 286-307. 
O’Connor, R. E., Bord, R. J., Fisher, A. (1999). Risk perceptions, general environmental beliefs, and willingness to address climate change. Risk analysis, 19(3): 461-471. Preston, I., Banks, N., Hargreaves, K., Kazmierczak, A., Lucas, K., Mayne, R., Downing, C., Street, R. (2014). Climate change and social justice: an evidence review. York: Joseph Rowntree.

Princen, T. (2010). Consumer Sovereignty, Heroic Sacrifice: Two Insidious Concepts in an Endlessly Expansionist Economy. In: Maniates, M. and Meyer. J. W. (eds.), The Environmental Politics of Sacrifice (pp. 145-164). Cambridge, MA: Massachusetts Institute of Technology Press.

Sandel, M. (2012). What Money Can't Buy: The Moral Limits of Markets. New York: Farrar, Straus and Giroux.

Schaffartzik, A., Mayer, A., Gingrich, S., Eisenmenger, N., Loy, C., Krausmann, F. (2014). The global metabolic transition: regional patterns and trends of global material flows, 1950-2010. Global Environmental Change, 26: 87-97.

Schaffrin, A. and Schmidt-Catran, A. (2017). Changing Concern about Environmental Threats and Risks - A Longitudinal and Multilevel Perspective on the Relationship Between Values and Interests. In: In: Telešienè, A. and Gross, M. (eds.), Green European. Environmental Behaviour and Attitudes in Europe in a Historical and Cross-Cultural Comparative Perspective (pp. 56-88). Abingdon: Routledge.

Simms, A., Johnson, V., Chowla, P., Murphy, M. (2010). Growth isn't possible: Why we need a new economic direction. London: New Economics Foundation and Schumacher College.

Skidelsky, R. and Skidelsky, E. (2012). How much is enough? Money and the good life. London: Penguin Books.

Spangenberg, J. H. (2005). Will the information society be sustainable? Towards criteria and indicators for a sustainable knowledge society. International Journal of Innovation and Sustainable Development, 1(1-2), 85-102.

Stiglitz, J. E. (2013). The Price of Inequality. London: Penguin Books.

Swyngedouw, E. (2010). Apocalypse forever? Post-political populism and the spectre of climate change. Theory, Culture \& Society, 27(2-3): 213-232.

Swyngedouw, E. (2014). Depoliticization ('The Political'). In: G. D’Alisa, G., Demaria, F., Kallis, G. (eds.), Degrowth: A Vocabulary for a New Era, (pp. 90-93). London: Routledge.

Szerszynski, B. (2010). Reading and writing the weather climate technics and the moment of responsibility. Theory, Culture \& Society, 27(2-3): 9-30.

Tammilehto, O. (2014). Rewarding with a licence to commit ecocide: High incomes and climate change. Degrowth Conference Leipzig. URL: http://www.degrowth. $\mathrm{de} / \mathrm{en} / \mathrm{catalogue}$-entry/rewarding-with-a-licence-to-commit-ecocide-high-incomes-and-climate-change/ (June, 2015).

Temper, L. 2015. Mapping the global battle to protect our planet. The Guardian online. URL: http://www.theguardian.com/global-development-professionals-network /2015/mar/03/mapping-environmental-protest-justice-defending-land (May 18, 2016). 
Timmons Roberts, J. and Parks, B. C. (2010). A "shared vision"? Why inequality should worry us. In: O’Brien, K., Lera St.Clari, A., Kristoffersen, B. (eds.), Climate Change, Ethics and Human Security (pp. 65-82). Cambridge: Cambridge University Press.

Torras, M., and Boyce, J. K. (1998). Income, inequality, and pollution: a reassessment of the environmental Kuznets curve. Ecological economics, 25(2): 147-160.

United Nations Climate Change Secretariat. (2015). Climate Action Now: Summary for Policymakers 2015. Bonn: United Nations Climate Change Secretariat.

Urry, J. (2011). Climate change and society. London: Polity.

Wapner, P. (2010). Sacrifice in an Age of Comfort. In: Maniates, M. and Meyer, J. W. (eds.), The Environmental Politics of Sacrifice (pp. 33-60). Cambridge, MA: Massachusetts Institute of Technology Press.

Wilkinson, R., and Pickett, K. (2010). The spirit level: why equality is better for everyone. London: Penguin Books.

Wright, E. O. (2011). Vizije realističnih utopija. Zagreb: Fakultet političkih znanosti. 


\title{
PROTIV POST-POLITIČKOG ODGOVORA NA KLIMATSKE PROMJENE: PREDSTAVLJANJE EGALITARNOG EUROPSKOG OKOLIŠTARCA
}

\author{
Oscar Krüger, Mladen Domazet i Danijela Dolenec
}

\begin{abstract}
Sažetak
Pitanje klimatskih promjena zahtjeva odgovor a oni koji tvrde da su predani oblikovanju tog odgovora nazivaju se okolištarcima. U društvenim istraživanjima, mnogo je napora uloženo u traganje za tim takozvanim okolištarcima, pri čemu se pokušalo razumjeti zašto ih na nekim geografskim i socijalnim prostorima pronalazimo a na drugima ne. Jedno od vodećih mišljenja u sociologiji okoliša jest da pokret za zaštitu okoliša proizlazi iz privilegiranog položaja imućnih članova društva.

U ovom radu iznosimo trostruku provokaciju - konceptualnu, empirijsku i političku - s ciljem da buduća istraživanja na ovu temu okrenemo u drugačijem smjeru. Konceptualno, inzistiramo na potrebi razlikovanja post-političkog od političkog pokreta za zaštitu okoliša, za što dajemo primjer društvenog pokreta za „smanjenje rasta” (engl. degrowth). Empirijski, pokazujemo da se istraživanja koja pokret za zaštitu okoliša prikazuju kao pokret imućnih oslanjaju na post-političku definiciju okolištaraca. Nadalje pokazujemo da ako vrijednosne orijentacije o okolišu povežemo sa smanjenjem rasta, dobivamo mnogo drugačiju kartu pokreta za zaštitu okoliša u Europi. Politički, ovo je izazov postojećim shvaćanjima onoga što je realistično u politici za naš europski kontinent ali $i$ izvan njega.
\end{abstract}

Ključne riječi: klimatske promjene, pokret za zaštitu okoliša, semi-periferija, pravda, smanjenje rasta

\section{GEGEN EINE POSTPOLITISCHE ANTWORT AUF DEN KLIMAWANDEL: VORSTELLEN DES EGALITÄREN EUROPÄISCHEN UMWELTSCHÜTZERS}

\author{
Oscar Krüger, Mladen Domazet und Danijela Dolenec
}

\section{Zusammenfassung}

Die Frage des Klimawandels bedarf einer Antwort und diejenigen, die behaupten, sich dieser Antwort zu widmen, nennt man Umweltschützer. Im Rahmen der Sozialforschung hat man sich viel Mühe gegeben, die sogenannten Umweltschützer zu finden, wobei man zu verstehen versuchte, warum man sie in manchen geografischen und sozialen Räumen finden kann und in anderen nicht. Eine der am meisten vertretenen Meinungen in der Umweltsoziologie ist, dass die Umweltschutzbewegung auf der privilegierten Stellung wohlhabender Gesellschaftsmitglieder beruht.

In dieser Arbeit liefern wir eine dreifache Provokation - im konzeptuellen, empirischen und politischen Sinne - mit dem Ziel, die zukünftige Forschung zu diesem Thema in eine andere Richtung zu wenden. Konzeptionell bestehen wir darauf, dass zwischen postpolitischer und politischer Umweltschutzbewegung unterschieden wird, wofür wir ein Beispiel geben, nämlich die soziale Bewegung für "Wachstumsrücknahme " (engl. degrowth). Empirisch zeigen wir, dass die Forschung, die Umweltschutzbewegung als eine Bewegung der Wohlhabenden darstellt, auf der postpolitischen Definition der Umweltschützer beruht. Weiterhin zeigen wir, dass eine viel unterschiedlichere Karte der Umweltschutzbewegung in Europa entsteht, wenn wir die Wertorientierung zur Umwelt mit einer Wachstumsrücknahme verbinden. Politisch ist das eine Herausforderung an die herkömmliche Meinung dazu, was in der Politik realistisch für das europäische Kontinet und darüber hinaus ist. Wir schließen mit einem kurzen Vorschlag:

Schlüsselwörter: Klimawandel, Umweltschutzbewegung, Halbperipherie, Gerechtigkeit, Wachstumsrücknahme 